\title{
47 Onderlagen en polstermateriaal
}

\section{Onderlagen}

Afhankelijk van soort en plaats van het functionele verband kan ter bescherming van een gevoelige huid een onderlaag worden aangebracht om direct contact van de tape met de huid te voorkomen. Een onderlaag kan ook worden gebruikt om voorgevormde delen en polsters op de huid te fixeren. Is bijvoorbeeld bij een zwelling een extra compressie-effect nodig, dan is het dunne, zowel in lengte- als breedterichting elastische Tricoplast ideaal. Voor het afdekken van grote oppervlakken, bijvoorbeeld aan de thorax, is het luchtdoorlatende, hypoallergene vlies Fixomull Stretch heel geschikt.

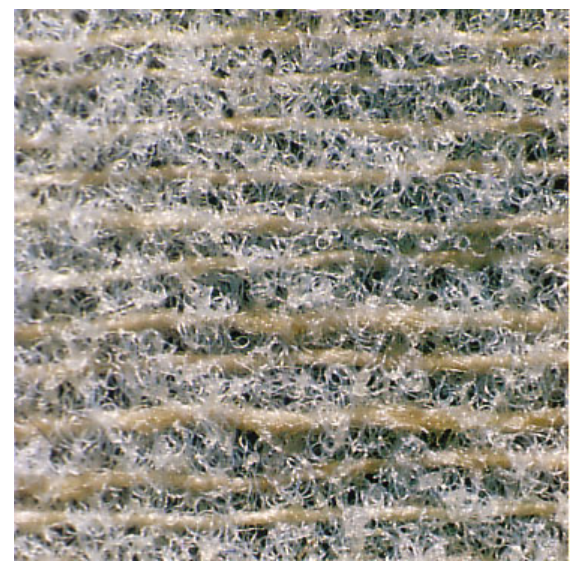

Gazofix is een cohesief elastisch fixeerverband dat alleen aan zichzelf hecht.
Niet-klevende onderlagen moeten, om een goed huidcontact te waarborgen, altijd in combinatie met kleefspray (Leukospray) worden toegepast.

Het elastische fixeerverband Gazofix is cohesief, dat wil zeggen dat het alleen op zichzelf hecht maar niet aan de huid of aan haren. Hiermee kan eenvoudig, snel en veilig een niet-glijdende en plooivrije onderlaag worden aangelegd, vooral aan de extremiteiten. Ook dunne lagen schuimstof kunnen als onderlaagmateriaal worden gebruikt.

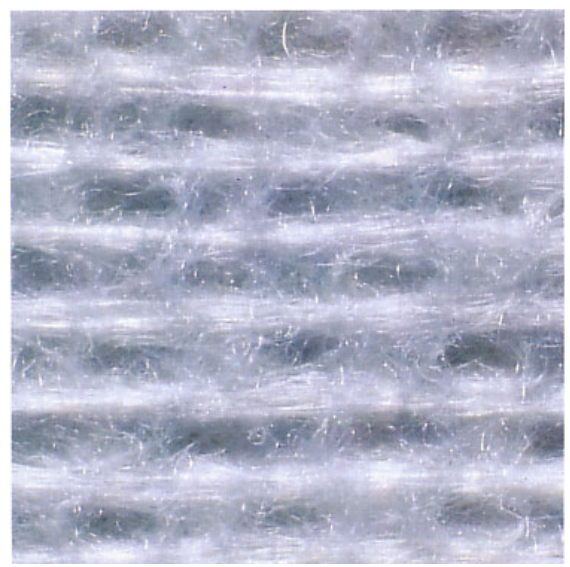

Fixomull Stretch, een zelfklevend vlies, is bijzonder geschikt als onderlaag voor grote oppervlakken.

\section{Polsters}

Het doel van een polster is de druk die het verband op het weefsel uitoefent gelijkmatig te verdelen. Om drukplekken te vermijden worden uitstekende delen, zoals uitstekende botten, met polstermateriaal afgevlakt. Door het opvullen van holtes kan oedeem op deze plekken worden voorkomen. Bovendien kan het polstermateriaal worden gebruikt als drager van percutaan werkende medicamenten.

Met textiel beplakt schuimrubber (Leukotape Foam) kan eenvoudig en snel in de gewenste vormen worden geknipt. Voor volledig opvullen is het vlies-polsterverband Artiflex geschikt.

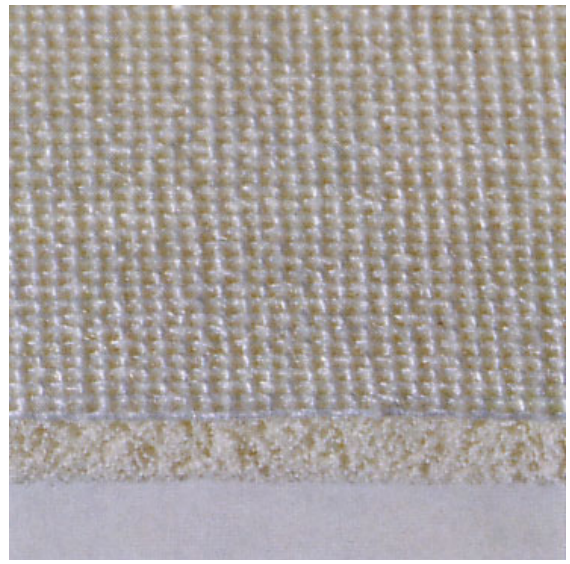

Van Leukotape Foam, een zacht, met textiel beplakt latexschuim, kunnen snel polsterdelen op maat worden geknipt. 